\title{
FINANCIAL SUSTAINABILITY OF HIGHER EDUCATION INSTITUTIONS
}

\author{
Jekaterina Kuzmina \\ BA School of Business and Finance, Latvia
}

\begin{abstract}
Since the beginning of the XXI century, there have been clear modifications in the sector of higher education, when the institutions have moved near to the economic sector. These changes were primary introduced as the consecutive response to the transformation processes within the society, which should be embedded in the following construct: there was a clear move towards a more competitive and market-based system. Due to the changes in the operating environment financial sustainability and its management for the higher education institutions became one of the core elements. The main objective of the current paper is to discuss the practical application of the methodology for the management of higher education institutions based on the example of Latvian private higher education institutions. The author would like to argue that the paper contributes to the fundamental discussion of financial sustainability in the field of higher education institution management. Moreover, it has got practical implications for the management of the organizations not only in Latvia but also in other countries when efficiency and effectiveness are primary issues.
\end{abstract}

Keywords: financial sustainability, higher education institutions, management.

\section{Introduction}

Decision-making and management process in higher education institutions is becoming complex and problematical due to the changes in technologies, operating environment, etc. Moreover, one should consider that in the XX century the higher education sector was valued as one with a lack of strong management due to the restricted competition, while at the beginning of the XXI century there was a transfer towards a more competitive and market-based system. Due to the changes in the operating environment financial sustainability and its management for higher education institutions became one of the core elements. Similar ideas have been discussed by several researchers (Cantwell et al., 2018; Hazelkorn et al., 2018; Aithal \& Kumar, 2019; Chyrva et al., 2020). The author is strongly convinced that the institutions' management providing higher education services needs to use stable methods of performance measurement and management not only to satisfy different stakeholders 'requirements but also to provide financial sustainability of the organization and its competitiveness in the long run. 
The purpose of the paper is to contribute to the current discussion about acceptable financial efficiency measurement suitable for allocation higher education institution's strategic goals (for the realization of strategies), as well as for performance measurement achieved by the organization, demonstrating how the Composite Financial Index can be applied and interpreted. The methodology is based on the financial ratio analysis and weighting optimization algorithm discussed in the previous works (Author, 2021). The current research paper is intended to discuss the practical application of the methodology for the management of higher education institutions based on the example of Latvian private higher education institutions.

\section{Literature Review}

It is worth considering that performance measurement and management played a considerable role in the academic discussion. As it was stated previously at the beginning of the XXI century the sector of higher education institutions has moved near to the economic sector and the kind of transformation has made the researchers paying attention to the performance measurement and management aspects in the particular domain. Higgins was one of the first authors who have settled the idea of the performance measurement system for higher education institutions (Higgins, 1989). According to him effectiveness and efficiency should be considered; while the system should be based on the three elements, including the mission of the organization, strategic analysis, and planning, management information system. The discussion has been developed by further scientists, who have established a significant decision matter within the management of higher education institutions like budgeting, allocation of resources, and performance management (Ho et al., 2006). Another group of scientists (Yu et al., 2009) has developed the idea of internal factors-based performance measurement and management, while the performance measurement should be considered as a supporting sub-system of performance management.

On the one hand, the mentioned research area is rather extensive, but on the other hand, there are some aspects that a covered less but are important and worth being recognized - the author would like to underline that there is widespread research on the field of performance measurement and management of higher education institutions, while the topic of financial wellbeing within this debate is less covered. Having done literature analysis, it is possible to claim that the mainstream of the researchers is describing the concept of performance measurement and management in the connection with efficiency discussion - scientists are linking performance management and measurement with the question of efficiency of the organization (Agasisti \& Dal Bianco, 2009; Agasisti \& Johnes, 2009; Wolszczak-Derlacz \& Parteka, 2011; 
Wolszczak-Derlacz, 2017; Bouzouita, 2019). While the other group (less numerous in the previous years, but probably increasing in the coming periods) is speaking about a combination of both efficiency and effectiveness factors (Taylor, 2014; De Witte \& López-Torres, 2017; Kretovics \& Eckert, 2019; Mukhtar et al., 2020).

Another conclusion out of the literature review was the fact that the financial efficiency of the higher education institution has been addressed by a limited number of research papers, for example, Ćwiąkała-Małys and Mościbrodzka are continuing their work on the field of financial efficiency evaluation in the domain of higher education and are covering several countries within the European Union in their discussion (Ćwiąkała-Małys \& Mościbrodzka, 2017). Tran and Villano are determining the divisional efficiency, as well as evaluating this efficiency concerning the overall performance of educational institutions within the Vietnamese higher education system (Tran \& Villano, 2018). Günay and Dulupçu have applied data envelopment analysis to quantify the comparative financial efficiency of the universities in Turkey (Günay \& Dulupçu, 2019). Mousa and Ghulam research the efficiency of institutions of higher learning in Saudi Arabia (Mousa \& Ghulam, 2019). Based on the findings described above the author is seeing the need to discuss the issue in particular, while the financial performance of the organization is one of the critical factors to ensure sustainable development. The question is getting more important when the sector of higher education institutions is struggling with demographic challenges in Latvia and has to face new global threats as COVID-19 pandemics.

\section{Research Methodology}

The author is using the methodology of ratio analysis in higher education developed by KPMG in cooperation with several researchers (Tahey et al., 2015), and adjusting it to the situation in Latvia. It is worth stating that some attempts to measure the financial sustainability of higher education institutions in Latvia were done by some researchers; but the author would like to renew the discussion and propose further development to the method. The reason for the renewed discussion is the fact that Mavlutova and Ziemele are covering in their paper a single organization (Mavlutova \& Ziemele, 2012), while Cernostana is applying a different method (Cernostana, 2018).

It is worth considering that the further discussion is going to be about the Composite Financial Index (CFI) covering the issues of liquidity, operational results, performance of assets, and debt and capital management. The CFI should be calculated based on measures and threshold levels as described in the table above (Table 1). The sum of the ratios previously adjusted to the strength as determined by threshold levels and the weight allow calculating the CFI. It should 
be underlined that the weighting of the ratios in the index represents the crucial issue and further clarification is necessary that is provided in the table below (Table 2). In order to make any strategical decisions applying the methodology described it will be necessary to collect information for 3 to 5 years and interpret the index value.

\section{Table 1 CFI: Explanation of Ratios and Threshold Levels}

\begin{tabular}{|c|c|c|}
\hline Financial Ratio for CFI & $\begin{array}{l}\text { Threshold Level, } \\
\text { Adjusted }\end{array}$ & Adjustment Reason \\
\hline $\begin{array}{l}\text { Primary Reserve Ratio } \\
\text { determined as net current assets } \\
\text { divided by total costs and is } \\
\text { measuring the level of financial } \\
\text { flexibility of the organization }\end{array}$ & $\begin{array}{l}\mathbf{0 . 2 5} \text { - meaning that the } \\
\text { organization to provide } \\
\text { financial flexibility should } \\
\text { provide around } 3 \text { months } \\
\text { of expenses }\end{array}$ & $\begin{array}{l}\text { adjusted based on } \\
\text { Latvian expert opinion }\end{array}$ \\
\hline $\begin{array}{l}\text { Viability Ratio is an indicator of } \\
\text { debt management and is equal to } \\
\text { net current assets divided by long- } \\
\text { term debt }\end{array}$ & $\begin{array}{l}1.25 \text { - average indicator } \\
\text { within the industry }\end{array}$ & $\begin{array}{l}\text { no adjustments are } \\
\text { made }\end{array}$ \\
\hline $\begin{array}{l}\text { Return on Net Assets is a measure } \\
\text { of economic return, indicating the } \\
\text { trend over years and it equals to } \\
\text { current period changes in net assets } \\
\text { divided by total net assets } \\
\text { multiplied by } 100\end{array}$ & $\begin{array}{l}\mathbf{4 \%} \text { as a healthy level also } \\
\text { considering the fact the } \\
\text { higher education institution } \\
\text { does not only fulfill the } \\
\text { business function, but also } \\
\text { a social one }\end{array}$ & $\begin{array}{l}\text { adjusted based on } \\
\text { Latvian expert opinion }\end{array}$ \\
\hline $\begin{array}{l}\text { Net Operating Revenues } \\
\text { measures the operating } \\
\text { performance of the organization } \\
\text { from day-to-day operations and is } \\
\text { calculated as net unrestricted } \\
\text { operating revenues divided by total } \\
\text { unrestricted operating revenues } \\
\text { multiplied by } 100\end{array}$ & $\begin{array}{l}\mathbf{2 . 5 9 \%} \text { - average indicator } \\
\text { within the industry in } \\
\text { Europe }\end{array}$ & $\begin{array}{l}\text { adjusted based on the } \\
\text { analysis of European } \\
\text { educational sector } \\
\text { public companies }\end{array}$ \\
\hline
\end{tabular}

Source: created by the author based on previous research (Tahey et al., 2015) and (Author, 2021).

Table 2 CFI: Explanation of Weighs

\begin{tabular}{|c|c|c|}
\hline Financial Ratio for CFI & Weight & Methodology \\
\hline Primary Reserve Ratio & $20.98 \%$ & \multirow{4}{*}{$\begin{array}{l}\text { weights are determined applying weight- } \\
\text { optimization algorithm as proposed by a } \\
\text { group of scientists (Becker et.al., 2017) to } \\
\text { solve the weighting issue discussed by the } \\
\text { author in the previous paper (Author, 2021). }\end{array}$} \\
\hline Viability Ratio & $58.40 \%$ & \\
\hline Return on Net Assets & $4.69 \%$ & \\
\hline Net Operating Revenues & $15.93 \%$ & \\
\hline
\end{tabular}

Source: created by the author. 


\section{Results of the Research}

Based on the literature analysis the author proposes, that the process of the higher education system could be constructed using comparable methods within the producing industry, and arrives at the conclusion about the necessity of a performance management system that could be presented as a 3-level concept described below (Fig. 1), where the decisions on the one level should have an impact on the judgments on the other levels. Introduction of Level I permits establishing a performance management framework with the purpose of improving the quality of the provided services to the students, public, etc. The goal could be achieved by publishing information on the performance. Moreover, one should consider that the concept should be seen as result-oriented, therefore the accountability of both efficiency and effectiveness ratios and indicators is necessary. The concept within this level could be organized as follows: 1) to describe goals/objectives; 2) to select the number of crucial indicators; 3) to assign goals/objectives and crucial indicators to the financial planning and strategical analysis, ensuring the persistent connection between goals/objectives and allocation of limited resources. The idea within the second level could be organized as following: 1) to ensure the monitoring/evaluation of the process (including the correction of errors); 2) to perform measurement of organizational and individual performance in a timely manner; 3) to provide consecutive reporting to the shareholders and internal as well as external stakeholders. Moreover, the current concept ensures the creation of the link to the strategic management policy within the organization on the condition that it provides the modification opportunity to the strategic management decisions due to the existing evaluation of performance. Within the current discussion, particular attention should be paid to step I, including measurement and evaluation of organizational performance. Moreover, the author would like to concentrate only on the issue of the financial health of the higher education institution, while the other aspects within the performance management system should be discussed in the further analysis. 


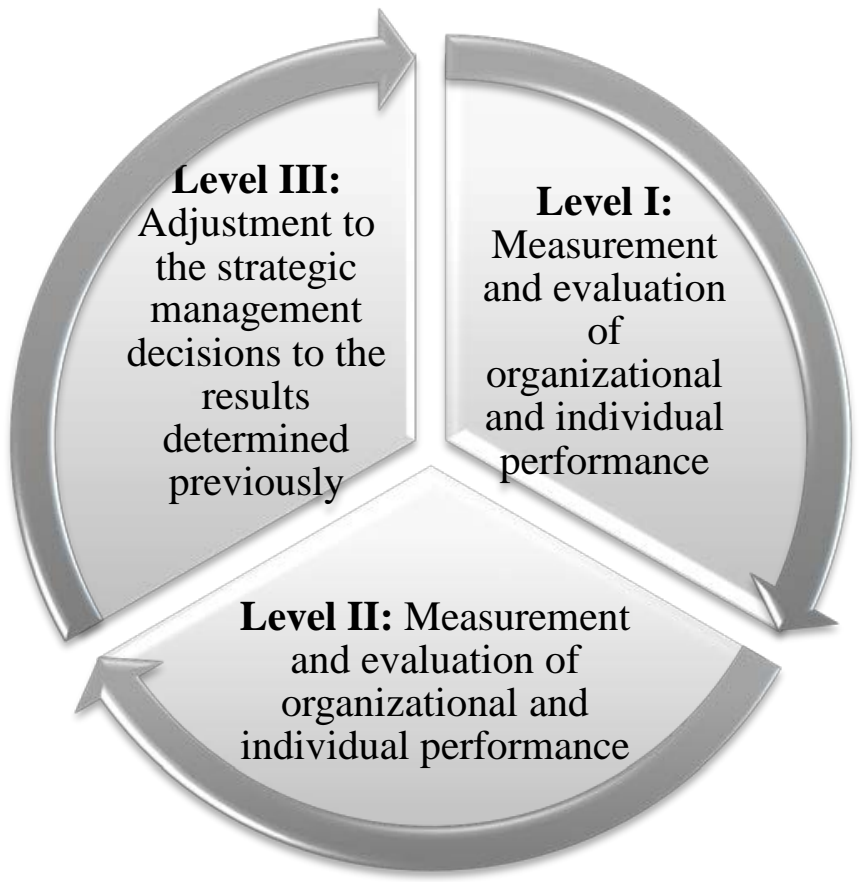

Figure 1 Performance Management System as 3-Level Concept (created by the author)

The latest OECD report states that public spending on higher education is moderately low in Latvia - around $0.9 \%$ of GDP in 2016 compared to $1.1 \%$ on average across the OECD countries. Moreover, this limited financial support does not reflect the increase in national wealth, which can be clearly identified by the following facts: between 2010 and 2016, Latvia's GDP increased by 21\%, while payments to the organizations providing education services fell by 24\% (OECD, 2020). Consequently, the financial performance and sustainability of the higher education institution are vital factors. Additionally, in the context of the current discussion it should be mentioned that there are different financial sources that a higher education institution could use, like state financial support for some public institutions (private higher education institutions are usually excluded from this channel); revenues coming from tuition fees (public higher education institutions are enjoying an additional benefit of so-called "budget-students", where the cash inflows are predefined); revenues from other services; private funds, etc. Consequently, the financial sustainability for private higher education institutions not benefiting (or benefits are very limited) from the government support is of particular importance as, on the one hand, they experiencing similar problems like decreasing number of students due to demographical factors in Latvia and the other Baltic States, aging of professors (even though the number of academic staff in Latvia is stabile during the last couple of years), as well as competition issues getting stiffer; while, on the other hand, have to satisfy shareholders' interests providing (or provided in the previous periods) the financial sources and 
evaluating a private higher education institution as a business or investment project. Additionally, new global threats as COVID-19 pandemics are making the issue of financial stability and long-term financial health more important for both public and private institutions. It is stated that in order to avoid any long-term negative effects from COVID-19 pandemics the institutions to pay greater attention to efficiency and effectiveness together with quality and value (Estermann et al., 2020).

The author would like to argue that the application of the described methodology is allowing to assess the financial health of the organization as well as to understand the possibilities and strategic implications in the changing environment. The current research is limited to the Latvia private higher education sector, while financial results from 13 organizations were analyzed retrieving the data from Lursoft - databases of enterprises. It is worth bearing in mind that the sample for the current research is limited to the number of private higher education institutions in Latvia operating in the sector for the last 5 years from 2015 to 2019 (excluding currently non-existent organizations), while the time period chosen for analysis of trends, calculation of ratios and determination of index is limited to the period as proposed by the existing research (Tahey et al., 2015) and confirmed by industry experts in Latvia. Due to the fact that the author would like to see the overall picture and determine CFI as a benchmark value suitable for further analysis of the particular institution providing higher education services the data are analyzed on the aggregated level - calculating the average ratios for the selected sample and determining the sub-industry CFI.

As indicated in Fig.2 there is financial resource sufficiency in private higher education institutions in Latvia, so that one can state that organizations were able to maintain a sufficient level of short-term financial stability above the threshold level during the analyzed period. Moreover, the data show a positive trend implying the ability of management to overcome short-term difficulties. The viability ratio addresses the problem of debt management within the organization - it indicates the improving trend (but the median is still below the threshold level), representing that analyzed education institutions do not have adequate funding to manage the debt effectively. The tendency specifies a particular problem that should be resolved otherwise it could endanger the existence of the organizations. Return on Net Assets indicates the investment performance of the organization. It should be considered that players from the sector were engaged in the investment activities in the previous periods hoping for a positive return in the coming years. The data indicates the positive trend, but it is worth considering that the performance ratio depends on several overall economic and social factors that cannot be controlled internally so that hikes should be evaluated with caution and limited optimism. Net Operating Revenues show an encouraging trend, but the overall level is still low and indicates the 
weakness of the private higher education institutions in Latvia in respect to the ability to operate within the level of the available resource.
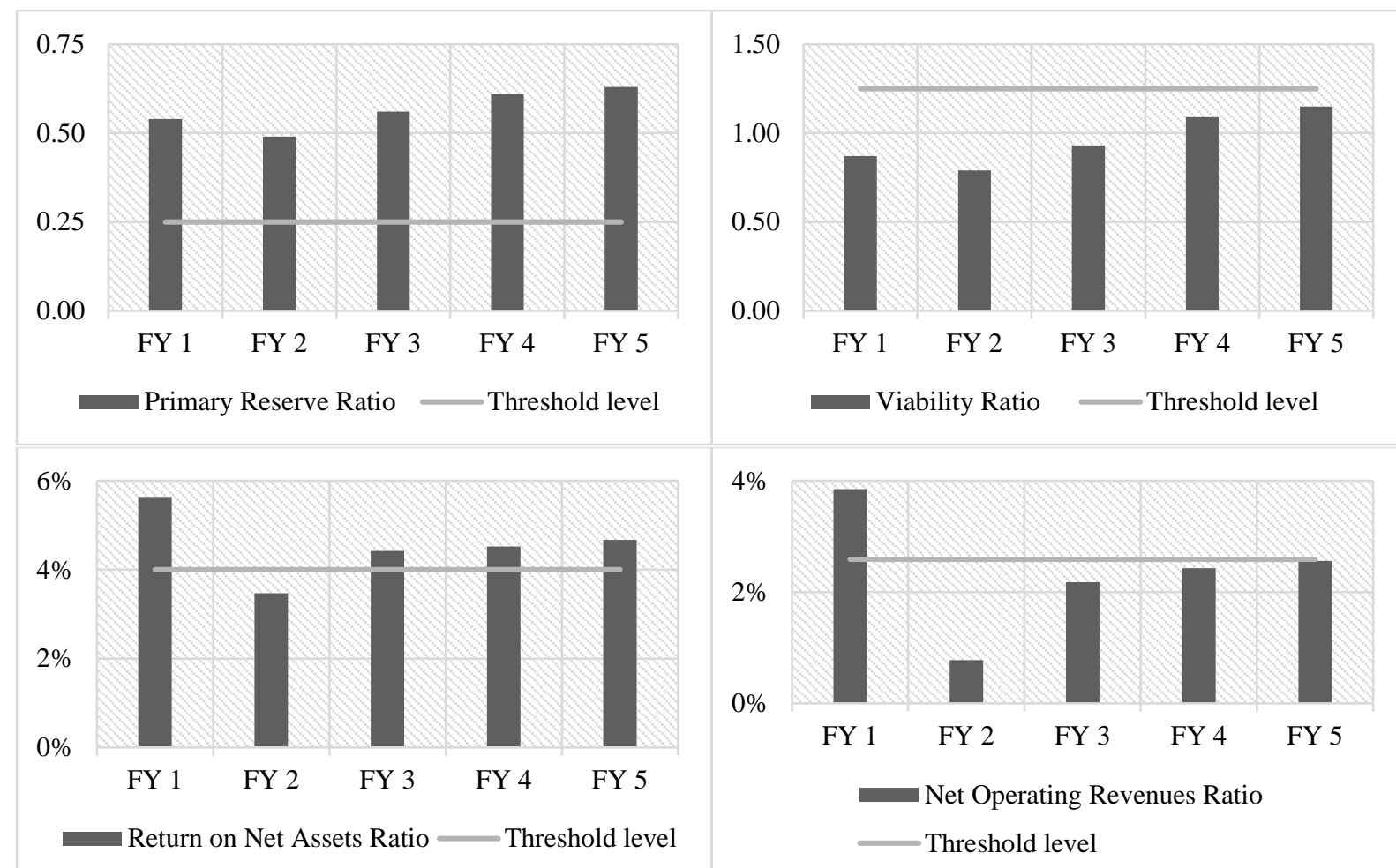

Figure 2 Ratios and Threshold Levels (calculated by the author)

It is worth considering that the kind of approach allows to maps each ratio's assessment on a diamond diagram to demonstrate the shape of the organization`s financial situation - indicating whether a considerable weakness is offset by a strength in another ratio and make a year-on-year comparison. The figure below (Fig. 3) shows that on the one hand private higher education institutions in Latvia demonstrates a particular weakness to operate within the level of the available financial resource (see levels of Net Operating Revenues (NOR)), but on the other hand, this drawback is balanced by other strength for example by resource sufficiency as determined by Primary Reserve Ratio (PRR) and ability to generate investment performance as described by Return on Net Assets Ratio (RoNA). Furthermore, it is worth underlying that in case of the absence of rare conditions, an organization would want at least the threshold level to be achieved, otherwise, this could be considered an indication of potential difficulties in the future (early warning signals). Besides, one should be able to recognize the positive signs of stabilization of financial health Latvian private higher education institutions in the last years (years 4 and 5 in the current analysis), which is less obvious otherwise. 
Proceedings of the International Scientific Conference. Volume VI, May $28^{\text {th }}-29^{\text {th }}, 2021.324-335$

Every ratio determined above displays the selected financial factor, further on it is divided by the strength of the factor and multiplied by the weight.

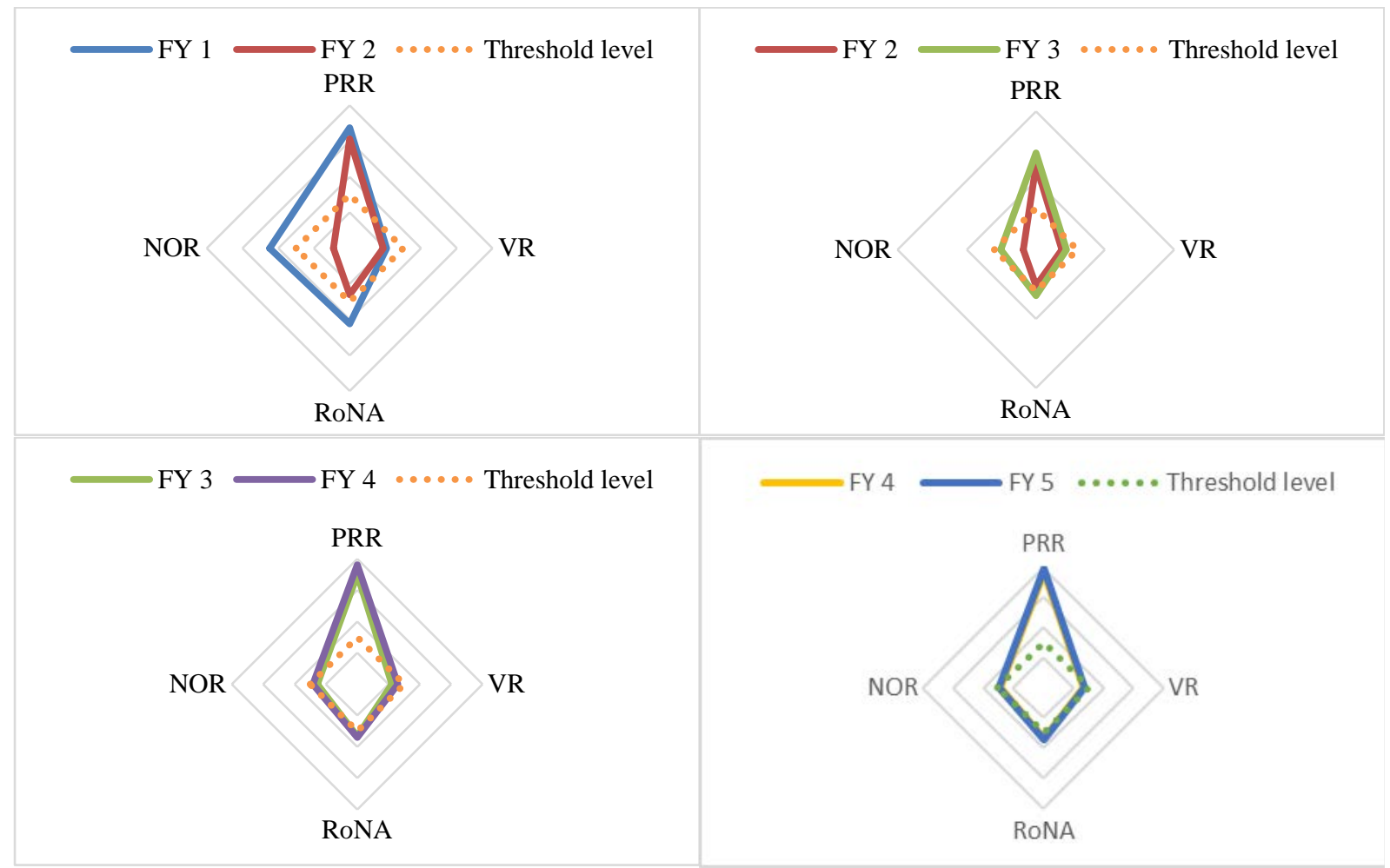

Figure 3 Ratio Comparison (calculated by the author)

As a result, the CFI is determined (Fig. 4) and it indicates the ability of the private higher education institution in Latvia to face the challenging business environment and the obligation to direct available financial resources to permit the transformation of the organizations to achieve their strategic purposes (the interpretation of the score is based on proposal by the American researchers (Tahey et al., 2015)).

Furthermore, the data shows a positive development trend in the previous periods that allows arguing that Latvian private higher education institutions are financially sustainable and able to compete in the challenging environment. Moreover, the calculated level of the index could be deliberated as a benchmark level and could be used for further analysis of the particular organization. 


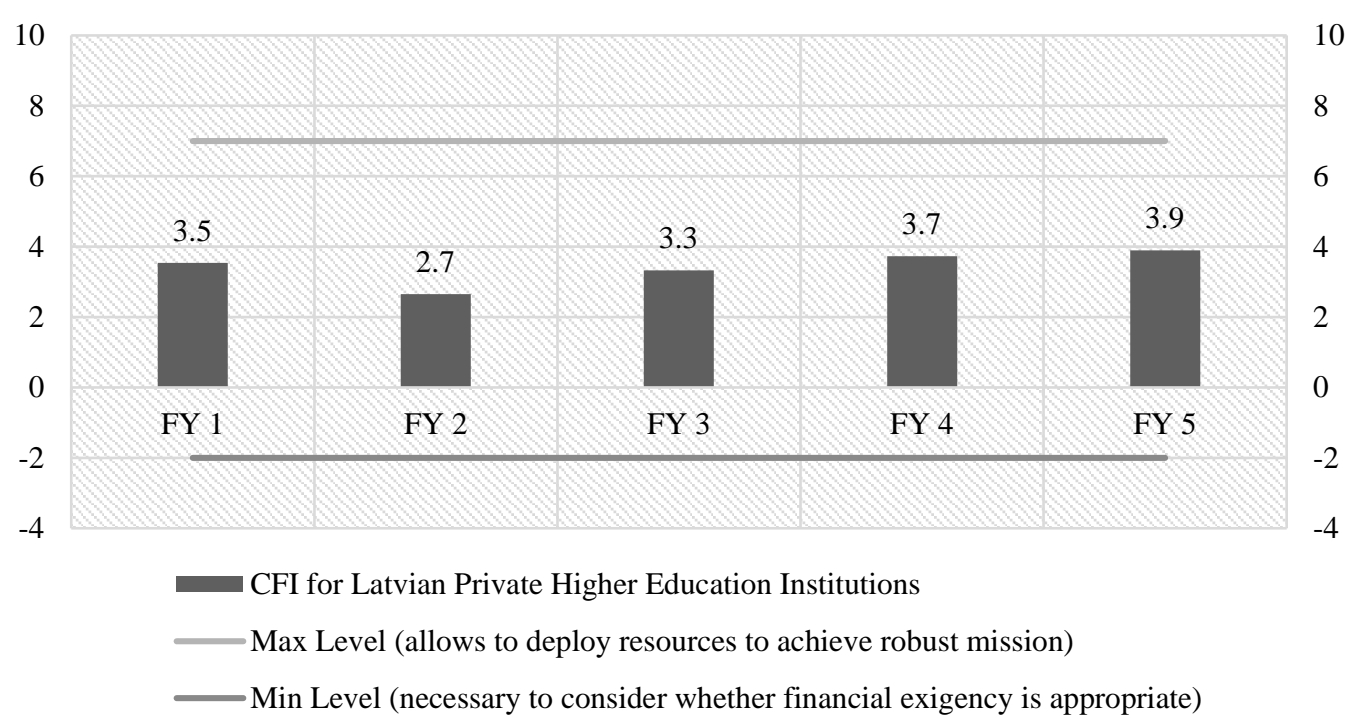

Figure 4 CFI for Latvian Private Higher Education Institutions (calculated by the author)

\section{Conclusions}

Based on the performed analysis the author has arrived at the following conclusions: management of the higher education institution is nowadays becoming multifaceted and requires additional tools to assure sustainable development of the organization. The existing research is addressing the subject only to the limited range, while the question of financial efficiency within this debate is less covered. The author would like to claim that the paper contributes to the fundamental debate of evaluation and efficiency measurement tools on the field of higher education institution and allows to determine further questions for analysis and scientific discussion like the inclusion of financial efficiency measurement in the ranking models for evaluation of higher education institutions among the pear group. Performed calculations allow determining that the level of financial health within Latvian private higher education institutions is sufficient to face the challenging business environment and it indicates the necessity to direct financial resources to allow the transformation of the organizations in the future. Moreover, the calculated CFI could be deliberated as a benchmark level and could be used for the further analysis of the performance of the particular organization that would provide supporting function in the managerial decisionmaking approach. Similar research applying the methodology described could be performed for public higher education institutions. Additionally, it could gain particular importance in the discussion of performance-based budgeting. This issue could be discussed in the coming paper. 


\section{References}

Agasisti, T., \& Dal Bianco, A. (2009). Measuring efficiency of higher education institutions. International Journal of Management and Decision Making, 10(5-6), 443-465.

Agasisti, T., \& Johnes, G. (2009). Beyond frontiers: comparing the efficiency of higher education decision-making units across more than one country. Education Economics, 17(1), 59-79.

Aithal, P. S., \& Kumar, P. M. (2019). Autonomy in Higher Education-Towards an Accountability Management Model. International Journal of Management \& Development, 6(10), 166-175.

Author. (2021). Article Title. In: Dz. Atstaja, V. Koval (Eds.), Knowledge management competence for achieving competitive advantage of professional growth and development: monograph (51-69). Riga: BA School of Business and Finance.

Becker, W., Saisana, M., Paruolo, P., \& Vandecasteele, I. (2017). Weights and importance in composite indicators: Closing the gap. Ecological indicators, 80, 12-22.

Bouzouita, A. (2019). Evaluating the efficiency of higher education institutions in Tunisia. International Journal of Education Economics and Development, 10(2), 212-233.

Cantwell, B., Coate, H., \& King, R. (Eds.). (2018). Handbook on the politics of higher education. Edward Elgar Publishing.

Cernostana, Z. (2018). Measuring financial sustainability of private higher education institutions. Engineering for rural development, 1173-1178.

Chyrva, O., Yashchuk, T., Pacheva, N., Berzhanir, A., \& Berzhanir, I. (2020). Modeling of the Processes of Formation and Effective Use of Financial Resources at Higher Education Institutions. TEM Journal, 9(1), 286-291.

Ćwiąkała-Małys, A., \& Mościbrodzka, M. (2017). Position of Chosen European Union Countries in Respect of Financial Efficiency of Higher Education in the Area of Didactics. Economic and Environmental Studies, 17(1 (41)), 83-93.

De Witte, K., \& López-Torres, L. (2017). Efficiency in education: a review of literature and a way forward. Journal of the Operational Research Society, 68(4), 339-363.

Estermann, T., Pruvot, E. B., Kupriyanova, V., \& Stoyanova, H. (2020). The Impact of the Covid-19 Crisis on University Funding in Europe: Lessons Learnt from the 2008 Global Financial Crisis. Briefing. European University Association. Retrieved from https://eua.eu/downloads/publications/eua\%20briefing_the\%20impact\%20of\%20the\%2 0covid-19\%20crisis\%20on\%20university\%20funding\%20in\%20europe.pdf

Günay, A., \& Dulupçu, M. A. (2019). Measurement of financial efficiency and productivity of Turkish Public Universities by using non-parametric methods. Journal of Applied Research in Higher Education.

Hazelkorn, E., Coates, H., \& McCormick, A. C. (Eds.). (2018). Research handbook on quality, performance and accountability in higher education. Edward Elgar Publishing.

Higgins, J. C. (1989). Performance measurement in universities. European journal of operational research, 38(3), 358-368.

Ho, W., Dey, P. K., \& Higson, H. E. (2006). Multiple criteria decision-making techniques in higher education. International Journal of Educational Management.

Kretovics, M. A., \& Eckert, E. (2019). Business practices in higher education: A guide for today's administrators. Routledge. 
Mavlutova, I., \& Ziemele, A. (2012). Composite financial index as a method to improve financial management at higher education institutions. Journal of Business Management, 1(6), 114-125.

Mousa, W., \& Ghulam, Y. (2019). Exploring efficiency differentials between Saudi higher education institutions. Managerial and Decision Economics, 40(2), 180-199.

Mukhtar, M., Hidayat, H., \& Habibi, S. (2020). Strategy Management in Improving the Effectiveness of Higher Education Management. International Journal of Education, Information Technology, and Others, 3(1), 171-179.

OECD. (2020). Education Policy Outlook: Latvia. OECD Publishing. Retrieved from http://www.oecd.org/education/policy-outlook/country-profile-Latvia-2020.pdf

Tahey, P., Salluzzo, R., Prager, F., Mezzina, L., \& Cowen, C. (2015). Strategic financial analysis for higher education: Identifying, measuring \& reporting financial risks. KPMG, Prager, Sealy, New York.

Taylor, J. (2014). Informing Or Distracting? Guiding Or Driving? the use of Performance Indicators in Higher Education. In: M. E. Menon, D. G. Terkla, \& P. Gibbs (Eds.), Using Data to Improve Higher Education: Research, Policy and Practice. Sense Publishers.

Tran, C. D. T., \& Villano, R. A. (2018). Financial efficiency of tertiary education institutions: A second-stage dynamic network data envelopment analysis method. The Singapore Economic Review, 1-22.

Yu, M. L., Hamid, S., Ijab, M. T., \& Soo, H. P. (2009). The e-balanced scorecard (e-BSC) for measuring academic staff performance excellence. Higher Education, 57(6), 813-828.

Wolszczak-Derlacz, J. (2017). An evaluation and explanation of (in) efficiency in higher education institutions in Europe and the US with the application of two-stage semiparametric DEA. Research Policy, 46(9), 1595-1605.

Wolszczak-Derlacz, J., \& Parteka, A. (2011). Efficiency of European public higher education institutions: a two-stage multicountry approach. Scientometrics, 89(3), 887-917. 